\title{
The mediating roles of job crafting and thriving in the LMX-employee outcomes relationship
}

\author{
Jie LI* \\ (Osaka University)
}

\begin{abstract}
Based on social exchange theory, I propose the mediating effects of job crafting and thriving in the relationship between leader-member exchange (LMX) and employee outcomes (i.e., affective commitment and job performance). To examine the proposed model, I conducted a survey of 277 subordinate-supervisor dyads in China. In support of the hypotheses, the results show that employees with a high quality of LMX are more likely to craft their jobs and thrive at work. It is also found that job crafting mediates the effect of LMX on affective commitment and that thriving mediates the effect of LMX on affective commitment and job performance. Implications and directions for future research are discussed.
\end{abstract}

Keywords : leader-member exchange, job crafting, thriving, affective commitment, job performance

\section{Introduction}

Prior research suggests that work context influences employees' attitudes and job performance (Levy \& Williams, 2004; Rosen, Harris \& Kacmar, 2011). In particular, those outcomes are influenced by employees' relationships with others at work, among which the relationship between supervisor and subordinate has received significant attention from researchers and practitioners (Ilies, Nahrgang \& Morgeson, 2007). Leader-member exchange (LMX, defined as the quality of the relationship between supervisors and their subordinates) is important for employees across organizations (Dienesch \& Liden, 1986). Research has shown that LMX can predict such employee outcomes as job satisfaction (Green, Anderson, \& Shivers, 1996), turnover intention (Harris, Wheeler \&

*Graduate School of Economics, Osaka University.
Kacmar, 2011), job performance (Moss, Sanchez, Brumbaugh et al., 2009), and organizational citizenship behavior (Liden, Sparrowe \& Wayne, 1997).

Although LMX is perceived as an important predictor of employee outcomes, metaanalytic studies reveal that a large number of these correlations are moderate or even weak (Harris et al., 2011). One explanation is that intervening mechanisms exist between these relationships (Schriesheim, Castro \& Cogliser, 1999). The processes through which managers encourage employees to perform well and develop favorable work attitudes have not been fully explored. The underlying mechanism of the LMX-employee outcomes relationship is an important research gap to address in organizational studies. In this article, I propose that high-quality interactions with supervisors make employees engage in proactive behaviors and develop positive psychological states, which in 
turn, impact their affective commitment and job performance.

Employees who have a good relationship with their supervisors gain more supervisory trust and resources than others, so they have more opportunities to move forward and initiate proactive actions (Harris et al., 2011). Therefore, I propose that high-quality LMX motivates employees to initiate self-starting and futureoriented changes, which are related to job crafting and thriving. Job crafting is defined as "the physical and cognitive changes individuals make in the task or relational boundaries of their work" (Wrzesniewski \& Dutton, 2001: 179), while thriving is defined as "the psychological state in which individuals experience both a sense of vitality and a sense of learning at work" (Spreitzer, Sutcliffe, Dutton et al., 2005: 538). Furthermore, I describe job crafting and thriving as engines to adjust employees' psychological states and job contents, and thus enhance their work attitudes and performance.

Overall, this article makes three major contributions. First, I provide further evidence on the importance of interactions between supervisors and subordinates. LMX is of special meaning for Asian employees, because they often highly respect authority (Hofstede, 2001). The results highlight the effect of LMX on employees' work attitudes and job performance. Second, I enrich the existing literature by providing a more fine-grained process in which LMX influences employees' work attitudes and performance. Specifically, I propose that high-quality interactions with their supervisors assure that employees will make things happen and grow at work. Finally, in the competitive and stressful business world, it is important for organizations to motivate their employees to thrive and adjust their job conditions proactively (Parker \& Col- lins, 2010). This article clarifies how LMX helps employees to achieve favorable outcomes.

\section{Theory and Hypotheses}

According to LMX theory, leaders develop unique relationships with each subordinate through a series of exchanges at work (Graen \& Uhl-Bien, 1995). The relationship between leader and follower involves a social exchange process such that LMX is enhanced by the exchange of resources, respect, and trust (Graen \& Scandura, 1987). LMX quality can shape employees' perception of mutual respect for and attachment to leaders. Indeed, numerous studies have illustrated that LMX quality influences employee performance (e.g., Harris et al., 2011; Rosen et al., 2011; Sue-Chan, Chen \& Lam, 2011).

Based on social exchange theory, I argue that good quality of LMX shapes positive social exchanges between supervisors and subordinates. Such social exchanges motivate employees to not only grow up and develop themselves at work, but behave more proactively (Blau, 1964; Rosen et al., 2011). A high quality of LMX would improve employees' work experiences, and exert a positive impact on their work attitudes and performance. More specifically, LMX influences employees' affective commitment and job performance through job crafting and thriving.

\section{1 LMX, Job Crafting, and Thriving}

Traditionally, employees are assigned customized job tasks by their organizations (Hackman \& Oldham, 1980). However, the fast-changing environment now requires employees to modify their jobs actively, instead of merely accept their job tasks passively (Tims, Bakker \& Derks, 2012; Wrzesniewski \& Dutton, 2001). Employees can 
craft their jobs in three forms: changing the job's task boundaries (e.g., the amount, schedule, or types of job tasks), relational boundaries (e.g., the interactions with others), and cognitive boundaries (e.g., the meaning and significance for one's job). Because job crafting involves a self-initiative process, it always happens without the involvement of management (Wrzesniewski \& Dutton, 2001). It may be risky or even threatening because changing boundaries of their jobs includes some drawbacks if not managed properly (Campbell, 2000; Magowan, 2012). Therefore, employees will not actively craft their jobs unless certain conditions obtain.

In this article, I propose that LMX is one of the important antecedents of job crafting. Because jobs and employees are embedded in the workplace, employees need to negotiate with their supervisors, colleagues, or clients to craft their jobs (Berg, Wrzesniewski \& Dutton, 2010). Generally, those with good relationships with supervisors have more resources and information to make job-related decisions. They also get more mentoring opportunities under complex contexts (Graen \& Scandura, 1987; Schriesheim et al., 1999). Those employees have more authority to influence other people, including their colleagues and subordinates. Therefore, employees with high-quality LMX can overcome barriers about relational constraints more easily than those with low-quality LMX, and they will perceive greater opportunities to job craft.

Moreover, LMX helps employees to obtain substantial resources (e.g., job autonomy), which are essential for job crafting (Sekiguchi, Li \& Hosomi, 2012). Employees with highquality LMX feel that they are supported, so their proactive behaviors are more likely to be accepted. In such a supportive environment, employees are encouraged to take initiative actions that go beyond their customary job requirements (Liden \& Graen, 1980). Indeed, Ilies and colleagues (2007) contend that LMX is related to organizational citizenship behavior, which is also beyond employees' core job roles. Similarly, I propose:

Hypothesis 1: LMX is positively related to employees' job crafting.

Thriving describes individuals' inner growth and development. It involves a self-development process, which focuses on employees' vitality and learning (Spreitzer et al., 2005). While vitality reflects one's perceived energy, learning involves one's acquiring and applying knowledge at work (Niessen, Sonnentag \& Sach, 2012; Porath, Spreitzer, Gibson et al., 2012). According to the relational perspective, vitality and learning are deeply rooted in the social network of the workplace. Therefore, thriving can be influenced by situational factors, among which interpersonal interactions are critical for their psychological states (Ryan \& Deci, 2000). Given the focal role of leaders in workplace, I propose that LMX potently influences employee thriving.

Researchers have noted that self-development occurs through interactions with other people (Miller \& Stiver, 1997). High-quality LMX involves positive conversations and mutual engagement between leaders and their followers, thus enhances employees' perceived competence and sense of belonging (Atwater \& Carmeli, 2009). Indeed, employees feel alive in a climate of trust and respect. Research has shown that such positive relationships can enhance a sense of empowerment, which in turn enhances employees' energy (Thomas \& Velthouse, 1990).

LMX also influences employees' learning at work. Similar to vitality, learning does not occur 
solely in isolation without interactions (Spreitzer et al., 2005). Instead, it is constrained by a work context in which employees get relational resources, observe others' work, and communicate with others (Brown \& Duguid, 1991). Learning requires interaction with other people to acquire new information and knowledge. Bezuijen and colleagues (2010) contend that LMX influences employees' engagement in learning activities. In particular, high-quality LMX motivates employees to engage in learning activities to reciprocate their leaders' trust.

Hypothesis 2: LMX is positively related to employees' thriving.

\subsection{Job Crafting, Thriving, Affective Commitment, and Job Performance}

Job crafting involves a process in which employees modify their jobs to better fit their work identity and meaningfulness (Ghitulescu, 2006; Wrzesniewski \& Dutton, 2001). Individuals who craft their jobs are more likely to experience subjective well-being and control over the workplace (Tims \& Bakker, 2010). Thus, it is reasonable to predict those employees who craft their jobs have positive work attitudes. Past research has indicated that job crafting may result in positive employee outcomes, such as resilience, job satisfaction, job effectiveness, work engagement, positive affectivity, organizational commitment, and employability (Bakker, 2010; Bakker, Tims \& Derks, 2012; Berg, Dutton \& Wrzesniewski, 2013; Ghitulescu, 2006; Tims et al., 2012; Tims, Bakker \& Derks, 2013).

In this article, I focus on affective commitment as an important employee outcome. Affective commitment refers to employees' emotional attachment to their organizations (Meyer \& Allen, 1991; Meyer, Allen \& Smith, 1993). By crafting their jobs, employees will perceive their jobs as more meaningful. In addition, they can better fit themselves into their jobs and workplaces. Thus, work will become more satisfactory and important for their sense of self (Ghitulescu, 2006). Consequently, they will feel that their organizations are more attractive, resulting in high affective commitment.

I do not predict that job crafting will enhance job performance. Because job crafters may change the amount of job tasks, schedule, and procedures with their understanding, they do not always achieve enhanced job performance (Campbell, 2000). For example, employees without enough professional knowledge or skills may adjust their jobs to fit their convenience. Under such circumstances, job crafting can be detrimental to their job performance.

Hypothesis 3: Employees' job crafting is positively related to their affective commitment.

In the supportive context, individuals have more opportunities to learn new knowledge and skills, so they are more likely to achieve optimal functioning and ultimate psychological growth (Porath et al., 2012; Spreitzer et al., 2005). Thriving is not the destination for those employees, and it can fuel positive attitudes and further agentic behaviors. That is, individuals' inner feelings of thriving serve as a gauge to adjust themselves to work contexts and behave proactively (Spreitzer et al., 2005). Employees who experience thriving are energized and have more passion for their work; they also acquire more knowledge and skills about their jobs to build self-efficacy and capability (Carver, 1998; Spreitzer \& Porath, 2012). Because those employees are aware of becoming better and developing themselves, they tend to develop positive attitudes toward their jobs (Porath et 
al., 2012). Consequently, they may become more committed to their current jobs and organizations.

As discussed earlier, thriving is also meaningfully associated with employees' job performance. Continuing to learn new knowledge and skills, employees may obtain more resources and better grasp their jobs. As a result, those employees not only learn more knowledge and skills at work, but also maintain their "aliveness" (Porath et al., 2012). Combined with energy at work, they have the fuel to perform well (Bruch \& Ghoshal, 2003; Porath et al., 2012). In addition, thriving experiences serve as internal cues in the self-regulation process (Spreitzer \& Porath, in press). High thriving individuals feel progress and momentum, and perceive competence and self-control, so they will behave proactively by taking their responsibilities and perform well (Grant \& Ashford, 2008). Such an argument is compatible with self-consistency theory (Korman, 1970), which suggests that individuals desire to maintain their self-perceptions and therefore act consistently. High thriving employees are more likely to develop favorable work attitudes and behave productively, which are consistent with their positive feelings.

Hypothesis 4: Employees' thriving is positively related to their job performance and affective commitment.

\subsection{Mediating Roles of Job Crafting and Thriving}

As noted earlier, a large number of studies have demonstrated the relationships between LMX and positive employee outcomes including affective commitment and job performance. However, research has not yet examined whether and how employees' job crafting and thriving may mediate these relationships. My theoretical framework posits the mediating effects of job crafting and thriving. Leaders and followers in good relationships exchange their resources; that is, leaders provide trust, relational resources, and support to their subordinates in exchange for the subordinates' effort and performance (Cropanzano \& Mitchell, 2005; Harris et al., 2011). This process should be manifested by employees' job crafting and thriving (Bindl \& Parker, 2010; Hackman \& Oldham, 1980).

Hypothesis 5: Employees' thriving mediates the relationship between LMX and their job performance and affective commitment.

Hypothesis 6: Employees' job crafting and thriving mediate the relationship between LMX and their affective commitment.

\section{Method}

\section{1 Sample and Procedures}

Data used in this study were collected as part of a large survey. Participants consisted of employees from a large state-owned company located in China. In consultation with the human resources managers, I invited 340 employees and their immediate supervisors from multiple departments. Survey packets were distributed during regular working hours. I attached a cover letter to ensure that participation was voluntary and that their responses were confidential. In addition, participants could withdraw from the process. Data were collected from different sources to alleviate the potential for common method bias (Podsakoff, MacKenzie, Lee \& Podsakoff, 2003). After the questionnaires were returned, I used a coding scheme to match responses from employees and those from their supervisors.

Two hundred and seventy-seven usable 
matched questionnaires were returned, an overall response rate of $81.5 \%$. Respondents were almost evenly split by gender, with $48.5 \%$ of them male. The mean age of participants was 39.49 years $(S D=7.41)$. On average, they had worked for 17.99 years $(S D=9.02)$ in the company. No significant differences were found between the average age, gender, and organizational tenure of respondents and non-respondents.

\subsection{Measures}

All the measurements used in this study were originally developed and validated in English or Japanese. Following the back-translation procedures, I translated them into Chinese to retain all the meanings of the items (Brislin, Lonner \& Thorndike, 1973). I also adjusted some wordings to fit the research context. All items were responded to a 7-point Likert scale from 1 (strongly disagree) to 7 (strongly agree).

LMX. I used Graen and Uhl-Bien's (1995) LMX-7 scale to measure the quality of employees' perceived relationships with their immediate supervisors. One sample item was "My supervisor understands my potential." The Cronbach's alpha coefficient was .80 .

Job crafting. Job crafting reflects the extent to which employees sculpt or reshape their jobs. Although Tims and colleagues (2012) developed a scale based on the job demands-resources (JD-R) model, it was primarily used in job stress studies. I assessed employees' job crafting using Sekiguchi and colleagues' (2012) 12-item scale, which is based on the Wrzesniewski and Dutton's (2001) conceptualization. Three dimensions, task crafting, relational crafting, and cognitive crafting were measured by four items each. Sample items included, "Change the content and/or procedure of my job to be more desirable" for task crafting, "Actively interact with people through my job" for relational crafting, and "Reframe my job as significant and meaningful" for cognitive crafting. The overall Cronbach's alpha coefficient was .90 .

Thriving. I measured participants' thriving using Porath and colleagues' (2012) 10-item scale. Two dimensions, learning and vitality were captured by five items each. Sample items included "At work, I find myself learning often" for the learning dimension, and, "At work, I have energy and spirit" for the vitality dimension. The overall Cronbach's alpha coefficient was .66.

Affective commitment. Consistent with prior research, I adopted five items that had the strongest loadings from the Allen and Meyer (1990) scale. A sample item was, "I really feel as if this organization's problems are my own." Cronbach's alpha coefficient was .78.

Job performance. Job performance reflects employees' in-role performance at work. Supervisors rated their subordinates' job performance on five positive worded items adopted from Williams and Anderson's (1991) measurement. A sample item was, "This employee fulfills responsibilities specified in the job description." Cronbach's alpha coefficient for this scale was .91 .

Control variables. I introduced several control variables to minimize the influences of exogenous variables. Employees' demographic information comprised the primary controls, including their gender (coded as $0=$ female, $1=$ male), age (in years), and organizational tenure (in years).

\section{Results}

Before testing the hypotheses, I performed a series of confirmatory factor analyses (CFAs) to examine the validity of the measurements. All 
the analyses were conducted via LISREL 8.80 (Jöreskog \& Sörbom, 2001). Because a large number of indicators may be problematic in CFAs, I parceled items under each construct such that each was examined by three items (Little, Cunningham, Shahar et al., 2002). The proposed five-factor baseline model showed an excellent fit to the data $\left(\chi^{2}[80]=174.00\right.$, $p<.001 ; \mathrm{CFI}=.97 ; \mathrm{NNFI}=.96 ; \mathrm{RMSEA}=.07)$ (Browne \& Cudeck, 1993), with all the indicators loaded on their intended latent variables (significantly at $p<.01$ level).

Table 1 presents the means, standard deviations, and correlations among the variables. LMX was positively correlated with job crafting and thriving $(r=.40, p<.01$ and $r=.37, p<.01$, respectively). Also, job crafting was positively correlated with affective commitment $(r=.49$, $p<.01)$. Finally, thriving was positively correlated with job performance and affective commitment $(r=.24, p<.01$ and $r=.31, p<.01$, respectively). All these results provide preliminary support for Hypotheses 1 through 4.

To examine Hypotheses 1 through 4, I conducted a series of regression analyses. For each equation, I first included the control variables, then I entered the predictors into the equation. The results are reported in Table 2.

Models 1 and 2 in Table 2 show that after controlling for employees' gender, age, and organizational tenure, LMX is positively related to job crafting $(\beta=.26, p<.01)$ and thriving $(\beta=.32$,

Table 1 Means, Standard Deviations, and Correlations among Variables

\begin{tabular}{|c|c|c|c|c|c|c|c|c|c|c|}
\hline & Mean & $S D$ & 1 & 2 & 3 & 4 & 5 & 6 & 7 & 8 \\
\hline 1. LMX & 4.80 & .91 & - & & & & & & & \\
\hline 2. Job crafting & 5.16 & .93 & $.40^{* *}$ & - & & & & & & \\
\hline 3. Thriving & 5.18 & .94 & $.37 * *$ & $.55^{* *}$ & - & & & & & \\
\hline 4. Job performance & 5.74 & .92 & $.24 * *$ & $.19 * *$ & $.24 * *$ & - & & & & \\
\hline 5. Affective commitment & 5.00 & .95 & $.23 * *$ & $.49 * *$ & $.31 * *$ & .09 & - & & & \\
\hline 6. Gender & .52 & .50 & .02 & $.17^{*}$ & $.15^{*}$ & $.15^{*}$ & $.24 * *$ & - & & \\
\hline 7. Age & 39.49 & 7.41 & .02 & -.01 & .02 & -.11 & .10 & -.05 & - & \\
\hline 8. Organizational tenure & 17.99 & 9.02 & .05 & .02 & .03 & $-.14^{*}$ & .13 & -.06 & $.90 * *$ & - \\
\hline
\end{tabular}

Notes. $N=277$.

Gender: 0 = female; 1 = male.

$* p<.05 ; * * p .01$.

Table 2 Results of Regression Analyses

\begin{tabular}{|c|c|c|c|c|}
\hline & $\begin{array}{c}\text { Model 1: } \\
\text { Job crafting }\end{array}$ & $\begin{array}{l}\text { Model 2: } \\
\text { Thriving }\end{array}$ & $\begin{array}{c}\text { Model 3: } \\
\text { Job performance }\end{array}$ & $\begin{array}{c}\text { Model 4: } \\
\text { Affective commitment }\end{array}$ \\
\hline Gender & $.16^{*}$ & $.14^{*}$ & .12 & $.16^{* *}$ \\
\hline Age & -.15 & .04 & .07 & -.05 \\
\hline Organizational tenure & .15 & -.01 & -.22 & .17 \\
\hline LMX & $.26^{* *}$ & $.32 * *$ & - & - \\
\hline Job crafting & - & - & .05 & $.39 * *$ \\
\hline Thriving & - & - & $.20 *$ & $.17 *$ \\
\hline Model $R^{2}$ & .10 & .12 & .11 & .33 \\
\hline
\end{tabular}

Notes. $N=277$.

$* p<.05 ; * * p<.01$.

Standardized coefficients are reported here. 
Table 3 Results of Multiple Mediation Analyses

\begin{tabular}{|c|c|c|c|c|c|c|c|c|}
\hline \multirow[b]{3}{*}{ Path analysis } & \multicolumn{4}{|c|}{ Dependent variable: Job performance } & \multicolumn{4}{|c|}{ Dependent variable: Affective commitment } \\
\hline & \multicolumn{2}{|c|}{ Job crafting } & \multicolumn{2}{|c|}{ Thriving } & \multicolumn{2}{|c|}{ Job crafting } & \multicolumn{2}{|c|}{ Thriving } \\
\hline & $\beta$ & $S E$ & $\beta$ & $S E$ & $\beta$ & $S E$ & $\beta$ & $S E$ \\
\hline IV-M & $.26^{* *}$ & .06 & $.27^{* *}$ & .06 & $.26^{* *}$ & .06 & $.27 * *$ & .06 \\
\hline M-DV & .03 & .06 & $.19^{*}$ & .09 & $.42 * *$ & .08 & $.19 *$ & .09 \\
\hline \multicolumn{9}{|l|}{ Bootstrapping } \\
\hline Indirect effect through $\mathrm{M}$ & -.00 & .03 & $.05^{*}$ & .00 & $.12 * *$ & .06 & .05 & .04 \\
\hline $\mathrm{BC} 95 \% \mathrm{CI}^{\mathrm{a}}$ & -.06 & .05 & .00 & .11 & .02 & .26 & -.01 & .13 \\
\hline Effect of IV on DV & $\beta$ & $S E$ & & & $\beta$ & $S E$ & & \\
\hline Total effect & $.22 * *$ & .07 & & & $.26^{* *}$ & .07 & & \\
\hline Direct effect & $.16^{*}$ & .07 & & & .10 & .07 & & \\
\hline & \multicolumn{4}{|c|}{ Model $R^{2}: .13^{* *}$} & \multicolumn{4}{|c|}{ Model $R^{2}: .34^{* * *}$} \\
\hline
\end{tabular}

Notes. $N=277$.

$* p<.05 ; * * p<.01$.

IV $=$ LMX.

${ }^{\mathrm{a}} \mathrm{BC}=$ Bias corrected; $\mathrm{CI}=$ Confidence interval.

Owing to space limitations, results for control variables are not reported here but are available from the author.

$p<.01$ ), supporting Hypotheses 1 and 2. Further, model 3 shows that thriving is positively related to job performance $(\beta=.20, p<.05)$ but the effect of job crafting on job performance is insignificant $(\beta=.05$, n.s.). Model 4 shows that job crafting and thriving are positively related to affective commitment $(\beta=.39, p<.01$ and $\beta=.17, p<.05$, respectively), supporting Hypotheses 3 and 4.

In the present study, I predicted that job crafting and thriving would serve as mediators between LMX and employee outcomes. Scholars usually use Baron and Kenny's (1986) analytic procedures to examine mediation effects. However, this method assumes that the samples are normally and symmetrically distributed. It may be problematic when analyzing a multiple mediation model (Preacher \& Hayes, 2008). Moreover, Baron and Kenny's (1986) method suffers from low statistical power, especially for small samples (MacKinnon, Lockwood, Hoffman et al., 2002). Therefore, I conducted nonparametric bootstrapping procedures to test the hypotheses. The results are reported in Table 3 .
The results of Table 3 show that for job performance as a dependent variable, after control variables are taken into account, LMX is positively related to job crafting $(\beta=.26, p<.01)$ and thriving $(\beta=.27, p<.01)$. In addition, thriving $(\beta=.19, p<.05)$ is significantly related to job performance when controlling for LMX. However, the effect of job crafting is non-significant $(\beta=.03$, n.s. $)$. Further results indicate that only the indirect effect of LMX on job performance through thriving $(\gamma=.05, p<.05 ; 95 \%$ CI $[.00, .11])$ is significant. Taken together, the mediating effect is confirmed and Hypothesis 5 was supported.

Examining Hypothesis 6, LMX is positively related to job crafting $(\beta=.26, p<.01)$ and thriving $(\beta=.27, p<.01)$ when employees' demographic information is controlled for. In addition, job crafting $(\beta=.42, p<.05)$ and thriving $(\beta=.19, p<.05)$ are significantly related to affective commitment when controlling for LMX. Further results indicate that the indirect effect of LMX on affective commitment through job crafting $(\gamma=.12, p<.01 ; 95 \%$ CI $[.02, .26])$ 


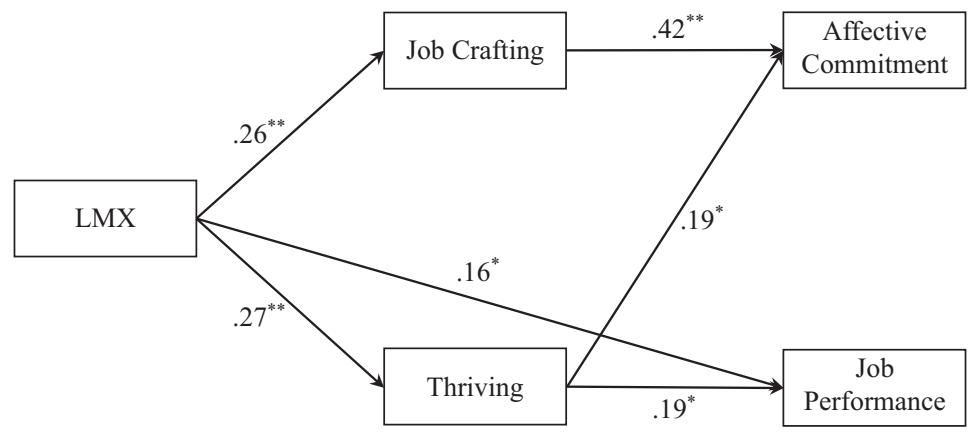

Notes. Standardized path coefficients are reported here. $* p<.05 ; * * p<.01$.

Figure 1 Path coefficients for the proposed model.

is significant, but the indirect effect through thriving is non-significant $(\gamma=.05$, n.s.; $95 \% \mathrm{CI}$ $[-.01, .13])$. Thus, Hypothesis 6 is partially supported. Figure 1 displays the path weights of the proposed model.

\section{Discussion}

Integrating social exchange theory (Blau, 1964) and the framework of LMX (Graen \& Uhl-Bien, 1995), I developed a theoretical model to examine how employees' perceptions of LMX influence affective commitment and job performance. This article focuses on employees' job crafting and thriving as intermediary mechanisms between LMX and employee outcomes. To test the hypotheses, I collected data from 277 subordinate-supervisor dyads in China. In line with the predictions, the results reveal that employees with high-quality LMX are more likely to craft their jobs and thrive at work. It is also found that job crafting mediates the effect of LMX on affective commitment and that thriving mediates the effect of LMX on affective commitment and job performance.

\subsection{Theoretical Implications}

This article contributes to the literature in several ways. First, it responds to Harris and col- leagues' (2011) call for future research on how LMX influences employee outcomes. I propose that job crafting and thriving link the pathways between LMX and employee outcomes. Major results in the present study indicate the robustness of prior findings of LMX research. In addition, the results demonstrate that employees' positive changes (i.e., behavioral and psychological) should be incorporated when exploring the quality of LMX as an important factor that contributes to their work attitudes and performance.

Moreover, it is important to note that results do not reveal a significant relationship between job crafting and job performance. Specifically, job crafting does not influence job performance significantly when controlling for thriving. Job crafting occurs at one's prescribed job, so employees can customize their jobs without their supervisors' guidance. Such findings indicate that the influences of proactive behaviors on employee outcomes are complex. When employees modify their jobs in a wrong direction, it may result in less productivity (Magowan, 2012). For example, employees who misunderstand their work contexts may adjust their jobs in a wrong direction. Thus, managers should be cautious in encouraging employees to craft their 
jobs.

Finally, this article contributes to the literature on thriving by examining leaders' roles in nurturing their employees' thriving experience. Prior research has focused on contextual features and resources, but ignores the role of leaders (i.e., leader-member exchanges) in shaping employees' vitality and learning experiences. I examined the influence that LMX may pose on employees' thriving. The results show that LMX should be associated with employees' thriving, which not only leads to affective reciprocity from subordinates but also to better performance. The partial mediation results of thriving for job performance suggest that the quality of LMX influences job performance both directly and indirectly, or that its effect may be mediated by other factors than thriving. Overall, the results indicate the importance of employees' psychological states in leadership effectiveness.

\subsection{Practical Implications}

This article contributes to managerial practices. Employees do not merely act passively to accomplish job tasks assigned to them, but can also behave proactively to develop themselves and help their organizations (Grant \& Ashford, 2008). As a first step to become more proactive, employees should pay more attention to developing good relationships with their supervisors in the workplace. High-quality LMX may lead to a supportive environment in which employees can take risks to engage in proactive behaviors and growth at work. On the other hand, in the complex business world, organizational success depends on employees' proactivity (Parker \& Collins, 2010). Thus, organizations can benefit from motivating employees to be more proactive and craft their jobs by providing a supportive context such as increasing the quality of LMX. These efforts can facilitate the fit that binds employees to the organizations, resulting in the development of a skilled workforce, improvement of work procedures, and other constructive changes that lead to better business performance.

\subsection{Limitations and Future Research}

Scholars should be cautious in applying these findings in the light of several limitations. First, most data except job performance are based on self-reported measures. However, it is unreasonable to measure some constructs using other-reported methods. For example, it is difficult for managers to observe employees' psychological states and attitudes. Job crafting behavior involves a cognitive deliberation process. Employees need to consider how to modify their jobs and interpersonal interactions at work. Also, cognitive crafting is hard for others to observe because other people do not understand the focal employees' perceptions. Therefore, it is appropriate to use self-reported measures in this study.

In addition, I collected data at only one company in China. Although the participants share most of the cultural beliefs and behaviors with other groups, this single sample may not be representative and influence the results. Despite the fact that scholars have indicated that research findings from China are highly consistent with that conducted in the West, we still need to consider the applicability of our results. Therefore, future research should replicate this study within other samples to strengthen the generalizability of the findings.

Finally, I used cross-sectional design to examine the hypotheses, thus cannot provide total support for causal inferences. Future research could adopt a longitudinal approach to reexam- 
ine the causal relationship among the variables. Such effort could also strengthen the validity of the research findings. Scholars may also include potential situational factors into the framework, such as job characteristics and initiative climate, to identify the boundary conditions of the proposed relationships.

\section{Acknowledgment}

I appreciate Professor Nobuaki Namiki and two anonymous reviewers for their insightful suggestions. I also thank the helpful comments on previous drafts from Professor Tomoki Sekiguchi. I am grateful to Dr. Jipeng Qi for his help with data collection.

\section{References}

Allen, N. J. \& Meyer, J. P. 1990 The measurement and antecedents of affective, continuance and normative commitment to the organization. Journal of Occupational Psychology, 63, 1-18.

Atwater, L. \& Carmeli, A. 2009 Leader-member exchange, feelings of energy, and involvement in creative work. Leadership Quarterly, 20, 264-275.

Bakker, A. B. 2010 Engagement and "job crafting": Engaged employees create their own great place to work. In S. L. Albrecht (Ed.), Handbook of employee engagement: Perspectives, issues, research and practice. Glos., UK: Edward Elgar, 229-244.

Bakker, A. B., Tims, M. \& Derks, D. 2012 Proactive personality and job performance: The role of job crafting and work engagement. Human Relations, 65, 1359-1378.

Baron, R. M. \& Kenny, D. A. 1986 The moderatormediator variable distinction in social psychological research: Conceptual, strategic, and statistical considerations. Journal of Personality and Social Psychology, 51, 1173-1182.

Berg, J. M., Dutton, J. E. \& Wrzesniewski, A. 2013 Job crafting and meaningful work. In B. J. Dik, Z. S. Byrne \& M. F. Steger (Eds.), Purpose and meaning in the workplace. Washington, DC: American Psychological Association, 81-104.

Berg, J. M., Wrzesniewski, A. \& Dutton, J. E. 2010 Perceiving and responding to challenges in job craft- ing at different ranks: When proactivity requires adaptivity. Journal of Organizational Behavior, 31, 158-186.

Bezuijen, X. M., van Dam, K., van den Berg P. T. \& Thierry, H. 2010 How leaders stimulate employee learning: A leader-member exchange approach. Journal of Occupational and Organizational Psychology, 83, 673-693.

Bindl, U. K. \& Parker, S. K. 2010 Proactive work behavior: Forward-thinking and change-oriented action in organizations. In S. Zedeck (Ed.), APA handbook of industrial and organizational psychology (Vol.2). Washington, DC: American Psychological Association, 567-598.

Blau, P. 1964 Exchange and power in social life. New York, NY: John Wiley.

Brislin, R. W., Lonner, W. J. \& Thorndike, R. M. 1973 Cross-cultural research methods. New York, NY: Wiley.

Brown, J. S. \& Duguid, P. 1991 Organizational learning and communities-of-practice: Toward a unified view of working, learning, and innovation. Organization Science, 2, 40-57.

Browne, M. W. \& Cudeck, R. 1993 Alternative ways of assessing model fit. In K. A. Bollen \& J. S. Long (Eds.), Testing structural equation models. Newbury Park, CA: Sage, 136-162.

Bruch, H. \& Ghoshal, S. 2003 Unleashing organizational energy. Sloan Management Review, 45, 45-51.

Campbell, D. J. 2000 The proactive employee: Managing workplace initiative. Academy of Management Executive, 14, 52-66.

Carver, C. S. 1998 Resilience and thriving: Issues, models, and linkages. Journal of Social Issues, 54, 245-266.

Cropanzano, R. \& Mitchell, M. S. 2005 Social exchange theory: An interdisciplinary review. Journal of Management, 31, 874-900.

Dienesch, R. M. \& Liden, R. C. 1986 Leader-member exchange model of leadership: A critique and further development. Academy of Management Review, 11, 618-634.

Ghitulescu, B. E. 2006 Shaping tasks and relationships at work: Examining the antecedents and consequences of employee job crafting. Unpublished doctoral dissertation, University of Pittsburgh.

Graen, G. B. \& Scandura, T. A. 1987 Toward a psychology of dyadic organizing. In B. Staw \& L. L. Cumming (Eds.), Research in organizational behavior (Vol.9). Greenwich, CT: JAI, 175-208.

Graen, G. B. \& Uhl-Bien, M. 1995 Relationship-based 
approach to leadership: Development of leader -member exchange (LMX) theory of leadership over 25 years: Applying a multi-level multi-domain perspective. Leadership Quarterly, 6, 219-247.

Grant, A. M. \& Ashford, S. J. 2008 The dynamics of proactivity at work. Research in Organizational Behavior, 28, 3-34.

Green, S. G., Anderson, S. E. \& Shivers, S. L. 1996 Demographic and organizational influences on leader-member exchange and related work attitudes. Organizational Behavior and Human Decision Processes, 66, 203-214.

Hackman, J. R. \& Oldham, G. R. 1980 Work redesign. Reading, MA: Addison-Wesley.

Harris, K. J., Wheeler, A. R. \& Kacmar, K. M. 2011 The mediating role of organizational job embeddedness in the LMX-outcomes relationships. Leadership Quarterly, 22, 271-281.

Hofstede, G. 2001 Culture's consequences: Comparing values, behaviors, institutions, and organizations across nations. Thousand Oaks, CA: Sage.

Ilies, R., Nahrgang, J. D. \& Morgeson, F. P. 2007 Leader-member exchange and citizenship behaviors: A meta-analysis. Journal of Applied Psychology, 92, 269-277.

Jöreskorg, K. \& Sörbom, D. 2001 LISREL 8: User's reference guide. Lincolnwood, IL: Scientific Software International.

Korman, A. K. 1970 Toward an hypothesis of work behavior. Journal of Applied Psychology, 54, 31-41.

Levy, P. E. \& Williams, J. R. 2004 The social context of performance appraisal: A review and framework for the future. Journal of Management, 30, 881-905.

Liden, R. C. \& Graen, G. 1980 Generalizability of the vertical dyad linkage model of leadership. Academy of Management Journal, 23, 451-465.

Liden, R. C., Sparrowe, R. T. \& Wayne, S. J. 1997 Leader-member exchange theory: The past and potential for the future. In G. Ferris (Ed.), Research in personnel and human resource management (Vol.15). Greenwich, CT: JAI Press, 47-119.

Little, T. D., Cunningham, W. A., Shahar, G. \& Widaman, K. F. 2002 To parcel or not to parcel: Exploring the question, weighing the merits. Structural Equation Modeling, 9, 151-173.

MacKinnon, D. P., Lockwood, C. M., Hoffman, J. M., West, S. G. \& Sheets, V. 2002 A comparison of methods to test the significance of the mediated effect. Psychological Methods, 7, 83-104.

Magowan, K. 2012 Job crafting: The concept and the ben- efits. Accessed on August 31, 2013 at http://leadingcompany.smartcompany.com.au/employeeengagement/job-crafting-the-concept-and-thebenefits/20120418705

Meyer, J. P. \& Allen, N. J. 1991 A three-component conceptualization of organizational commitment. Human Resource Management Review, 1, 61-89.

Meyer, J. P., Allen, N. J. \& Smith, C. A. 1993 Commitment to organizations and occupations: Extension and test of a three-component conceptualization. Journal of Applied Psychology, 78, 538-551.

Miller, J. B. \& Stiver, I. P. 1997 The healing connection: How women form relationships in therapy and in life. Boston, MA: Beacon Press.

Moss, S. E., Sanchez, J. I., Brumbaugh, A. M. \& Borkowski, N. 2009 The mediating role of feedback avoidance behavior in the LMX-performance relationship. Group $\mathcal{E}$ Organization Management, 34, 645-664.

Niessen, C., Sonnentag, S. \& Sach, F. 2012 Thriving at work: A diary study. Journal of Organizational Behavior, 33, 468-487.

Parker, S. K. \& Collins, C. G. 2010 Taking stock: Integrating and differentiating multiple proactive behaviors. Journal of Management, 36, 633-662.

Podsakoff, P. M., MacKenzie, S. M., Lee, J. \& Podsakoff, N. P. 2003 Common method biases in behavioral research: A critical review of the literature and recommended remedies. Journal of Applied Psychology, 88, 879-903.

Porath, C., Spreitzer, G., Gibson, C. \& Garnett, F. G. 2012 Thriving at work: Toward its measurement, construct validation, and theoretical refinement. Journal of Organizational Behavior, 33, 250-275.

Preacher, K. J. \& Hayes, A. F. 2008 Asymptotic and resampling strategies for assessing and comparing indirect effects in multiple mediator models. Behavior Research Methods, 40, 879-891.

Rosen, C. C., Harris, K. J. \& Kacmar, K. M. 2011 LMX, context perceptions, and performance: An uncertainty management perspective. Journal of Management, 37, 819-838.

Ryan, R. M. \& Deci, E. L. 2000 Self-determination theory and the facilitation of intrinsic motivation, social development, and well-being. American Psychologist, 55, 68-78.

Schriesheim, C. A., Castro, S. L. \& Cogliser, C. C. 1999 Leader-member exchange (LMX) research: A comprehensive review of theory, measurement, and data-analytic practices. Leadership Quarterly, 
The mediating roles of job crafting and thriving in the LMX-employee outcomes relationship

10, 63-113.

Sekiguchi, T., Li, J. \& Hosomi, M. 2012 Determinants of job crafting among part-time and full-time employees in Japan: A relational perspective. Paper presented at the 8th Asia Academy of Management Conference, Seoul, Korea.

Spreitzer, G. M. \& Porath, C. 2012 Creating sustainable performance. Harvard Business Review, 90, 92-99.

Spreitzer, G. M. \& Porath, C. in press. Self-determination as nutriment for thriving: Building an integrative model of human growth at work. In M. Gagne (Ed.), The Oxford handbook of work engagement, motivation, and self-determination theory. New York, NY: Oxford University Press.

Spreitzer, G. M., Sutcliffe, K., Dutton, J., Sonenshein, S. \& Grant, A. M. 2005 A socially embedded model of thriving at work. Organization Science, 16, 537-549.

Sue-Chan, C., Chen, Z. \& Lam, W. 2011 LMX, Coaching attributions, and employee performance. Group E Organization Management, 36, 466-498.

Thomas, K.W. \& Velthouse, B. A. 1990 Cognitive ele- ments of empowerment: An interpretive model of intrinsic task motivation. Academy of Management Review, 15, 661-681.

Tims, M. \& Bakker, A. B. 2010 Job crafting: Towards a new model of individual job redesign. SA Journal of Industrial Psychology, 36, 1-9.

Tims, M., Bakker, A. B. \& Derks, D. 2012 Development and validation of the job crafting scale. Journal of Vocational Behavior, 80, 173-186.

Tims, M., Bakker, A. B. \& Derks, D. 2013 The impact of job crafting on job demands, job resources, and well-being. Journal of Occupational Health Psychology, 18, 230-240.

Williams, L. J. \& Anderson, S. E. 1991 Job satisfaction and organizational commitment as predictors of organizational citizenship and in-role behaviors. Journal of Management, 17, 601-617.

Wrzesniewski, A. \& Dutton, J. E. 2001 Crafting a job: Revisioning employees as active crafters of their work. Academy of Management Review, 26, 179-201.

(Received September 26, 2013 Accepted June 4, 2014) 